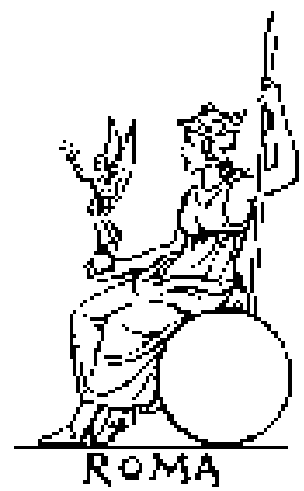

\title{
Review
}

Reviewed Work(s): Studi Romani: Rivista di Archeologia e Storia by

Review by: Thomas Ashby

Source: The Journal of Roman Studies, Vol. 2 (1912), pp. 280-281

Published by: Society for the Promotion of Roman Studies

Stable URL: http://www.jstor.org/stable/295969

Accessed: 18-09-2016 10:42 UTC

JSTOR is a not-for-profit service that helps scholars, researchers, and students discover, use, and build upon a wide range of content in a trusted digital archive. We use information technology and tools to increase productivity and facilitate new forms of scholarship. For more information about JSTOR, please contact support@jstor.org.

Your use of the JSTOR archive indicates your acceptance of the Terms \& Conditions of Use, available at http://about.jstor.org/terms

Cambridge University Press, Society for the Promotion of Roman Studies are collaborating with JSTOR to digitize, preserve and extend access to The Journal of Roman Studies 
central Europe and in Africa, was its Romanisation of the native peoples. That is a feature which does not, and which practically cannot, recur in the British empire, and it supplies perhaps the most fundamental contrast between the two states. Those who fail to realise it can never fully understand what in the end the Roman empire achieved. The Romans themselves in their first days of empire hardly understood it. 'The great lines of Virgil which everyone knows and quotes, " tu regere imperio populos, etc." embody a poor conception of the work, the real work, of the empire. For a truer account we must turn to a poct of much later date and not of Italian birth, who, in the last age of Roman rule in the west, could praise the empire thus :

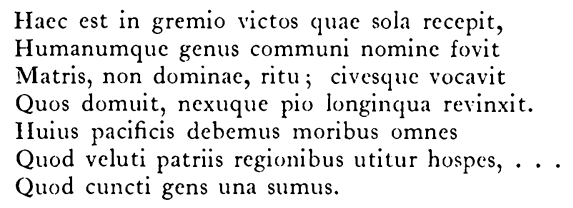

Another contrast which Sir Charles mentions in language scarcely likely to enforce it on his readers is the following. The world in which the British empire exists is one which contains much other Furopean civilisation and that civilisation seems strong and unlikely to perish; the Roman had to fence his frontiers in order to keep any tolerable civilisation alive in the world at all. Sir Charles tells us that " taken as a whole, British trade and colonisation have known no limits. 'The policy has not been that of the Roman Wall." But Roman Walls were not barriers against the expansion of Rome, nor, as many finds in Germany show, did they mark the limits of Roman trade. There was expansion beyond the frontier, when "levissimus quisque Gallorum " emigrated into the "agri decumates" and drew the frontier line after them. On the other hand, the whole drift of recent colonial policy in respect to Chinese and other immigrants into Australia, New Zealand, South Africa, British Colombia, has been precisely the policy of the Roman Wall, expressed in legal rather than military forms. It has set a barrier against the incoming of peoples who have been judged likely to wreck or damage the European type of civilisation.

\section{F. Haverfield.}

STUDI ROMANI : RIVIS'TA DI ARCHEOLOGIA E STORIA, ANNo I, FAsc. i. IO $\times 6 \frac{1}{2} .68 \mathrm{pp}$. 7 plates. Rome, 1913. Annual subscription, 20 lire for Italy, 25 lire for abroad.

The programme of this new review states that it is intended to demonstrate that Rome and the civilisation which she spread over the Roman world have equal claims to consideration with Greece and Greek civilisation. Even though we must concede to the latter the primacy in art and philosophy, Rome can hold her own in the development of the conceptions of the state and of the citizen, with all that they involve, public and private law, government, commerce, architecture, and so forth.

The aim is a legitimate one, for the Greek deities have taken more than their just revenge for the scorn once lavished on the Elgin marbles, and Rome has now to fight hard for her place in the sun; whereas there should be room for both without rivalry. Comparisons are surely never more odious than when they are unnecessary.

The list of contributors to the new periodical is certainly a good one : and the contents of the first number, though devoted entirely to points of detail, and somewhat lacking in interest of a gerieral character, represent, to those who know Rome well, genuine contributions to our knowledge. Thus Signor Mancini gives an account of the discoveries recently made on the site of the new chamber of deputies at Monte Citorio. 
Some forty feet below ground, and below the present river level, was excavated a drainage canal, completely constructed of wood, while other piles werc encountered somewhat higher up; plans and sections would have added to the interest of the account. At the imperial level an ustrinum was met with very similar to that discovered in 1703 : they are identified respectively as the ustrinum of Antoninus Pius and that of Marcus Aurelius.

Prof. Amelung follows with a short note on the so-called bust of Belisarius which still occupies its niche against the Aurelian wall, almost the only surviving trace of the beauties of the villa Ludovisi; now given up to modern hotels; and he finds in it a portrait of Alexander the Great of a new type.

The third article, by Signor Maiuri, deals with an interesting inscription of A.D. 194 of the phratria of the Artemisii, recently discovered in Naples; it contains the decree conferring certain honours on L. Munatius Hilarianus, a member of the phratria, for his munificence in adorning its meeting-rooms and in building a shrine of Artemis, and his reply refusing a part of these honours, and promising further liberalities.

The fourth article is a careful study of the basilica of S. Lorenzo fuori le Mura by Prof. Pesarini, in which he comes to the conclusion, as against the views of G. B. de Rossi, that no part of the existing building can be attributed to Constantine, that the basilica which Sixtus III $(432-440)$ erected in honour of St. Lawrence was in reality S. Lorenzo in Lucina, and that the posterior portion of the existing church was built by Pelagius II (579-590), and lengthened by Honorius III (1216-1227), who destroyed the original apse and reversed the orientation.

The last article, by Father F. Grossi Gondi, deals with the confessio and the papal chair at S. Lorenzo in Lucina, works of the year 1112 , both hidden by the massive high altar erected by Carlo Rinaldi in 1675. A short section devoted to Notizie follows, in which reports of scientific meetings and new discoveries are announced.

Thomas Ashiy.

MITTEILUNGEN DER ALTERTUMS-KOMMISSION FÜR WESTFALEN. Vol. VI. $9 \$ \times 6 \$$, 124 pp. 20 plates and many illustrations in the text. Munster i. W. 1912. Mks. 10.

The fifth volume of this series, issued in 1909 , brought the tale of the Haltern excavations down to the end of the year 1907. The volume before us describes the work done in 1908-19ro, and as excavation was suspended in Igr I and seems to have yielded few results in 1912 , it may be said to bring the reports on the results attained at Haltern practically up to date. It is written by Dr. F. Koepp and others, and is marked by the same care and minuteness, and fitted with the same wealth of illustration, as the earlier reports. The chief discoveries of the years in question, 1908-1910, appear to have been two. (I) Just behind the praetorium, and indeed just opposite what may be called its backdoor, the excavators discovered the remains of the Haus des Legaten, ill-preserved but recognisable. Apparently the backdoor in the praetorium was intended to communicate with this ; it served much the same end as the "bolt-hole" by which, in some Oxford and Cambridge colleges, the dons reach or leave the high table. The relation of the commanding officer's house to the praetorium is, therefore, very much like that of the "quaestorium" at Carnuntum. The area of the house is about 40 by $50 \mathrm{~m}$. Its plan which seems, not unpardonably, to have much puzzled the excavators, may be described as that of a small central open court, surrounded by six pillars which bore a colonnade and by rooms which opened thereon: behind this quasi-atrium were other rooms and possibly a second coure, of which the traces are fragmentary. The whole seems to me simply a much greater and more magnificent edition of the little commandant's house which has been found in auxiliary castella, at Housesteads, at Hofheim, probably at Gellygaer, and elsewhere. (2) Much interest attaches to a largish find of Arretine 